\title{
Yellow starthistle continues its spread in California
}

by Michael J. Pitcairn, Steve Schoenig,
Rosie Yacoub and John Gendron

Yellow starthistle is an exotic invasive weed that is estimated to infest over 14 million acres in California and is considered the most common exotic weed statewide. We reviewed several previous studies and conducted a township survey to provide an up-to-date analysis of the weed's rapid spread throughout the state. A county-by-county comparison between 1985 and 2002 showed increases in yellow starthistle in all regions of the state except for northeast California and the southeast desert region. Currently, most infestations occur in Northern California, but future invasions and spread will likely occur in the coastal counties of Southern California.

Y ellow starthistle is an exotic, noxious weed commonly found in rangelands and along roadsides and walking trails throughout California. Approximately 1-inch-long spines extend from the flower heads in a starlike pattern, giving rise to its common name of "starthistle." These spines are a bane to hikers and discourage feeding by grazing animals. Although not toxic to most animals, yellow starthistle (Centaurea solstitialis L. [Asteraceae]) is poisonous to horses and can cause brain lesions that may eventually kill them (Cordy 1978). Yellow starthistle favors disturbed soils but is also capable of invading undisturbed areas. Once this weed gains a foothold, it can build up dense populations that displace native and other desirable vegetation. Yellow starthistle is native to the Mediterranean climates of southern Europe and northern Africa and was first recorded in California near Oakland (Alameda County) in 1869. It is now considered the most common weed in the state.

Yellow starthistle was likely introduced many times to California as a

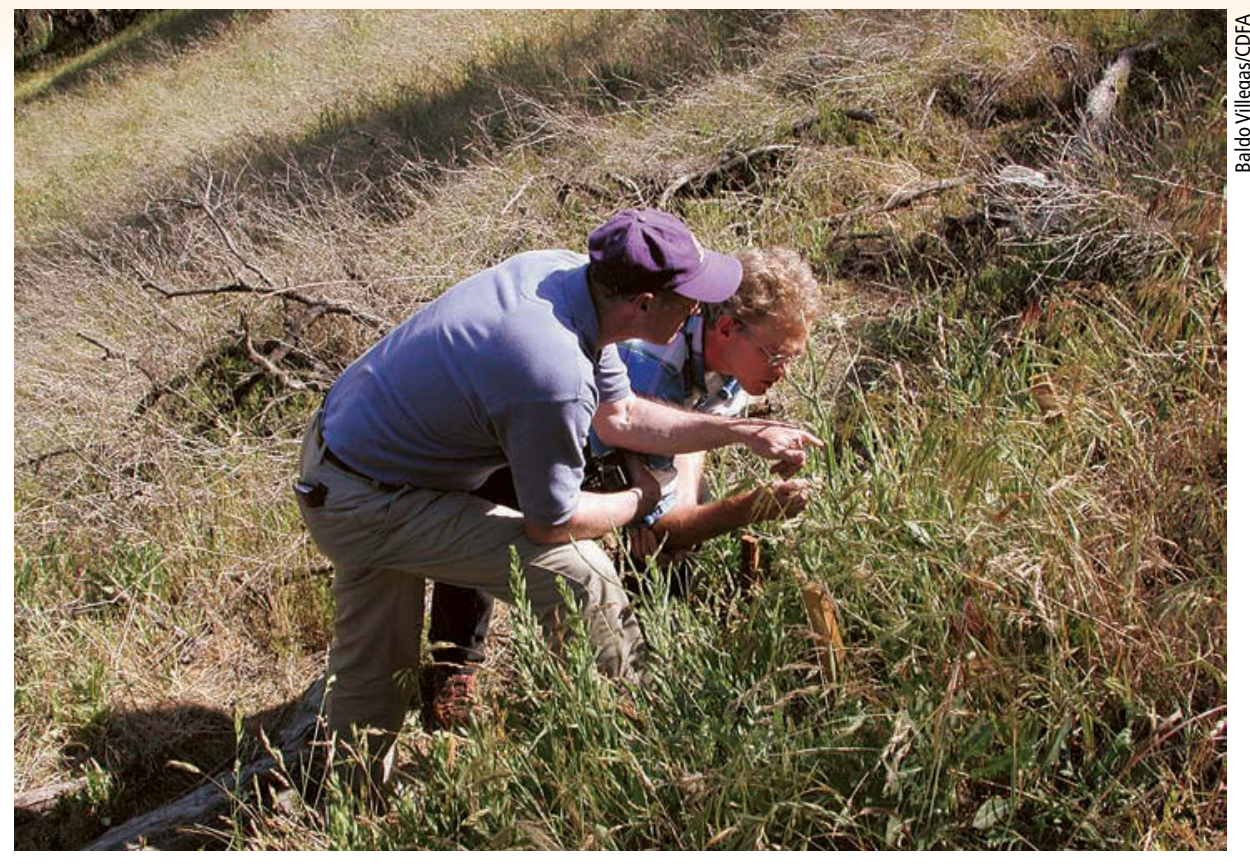

Yellow starthistle is the fastest-moving and most-widespread invasive, nonnative plant in California history. Dale Woods of the California Department of Food and Agriculture and Bill Bruckart of the U.S. Department of Agriculture examine the weed in Placer County.

contaminant of alfalfa seed (DiTomaso and Gerlach 2000). In the late 1800s, alfalfa seed from Europe, Asia and South America was imported for planting in the Sacramento Valley, and early records show that yellow starthistle was a frequent contaminant in these shipments. By 1917, this weed was common along roads, trails, ditches and railroad tracks throughout the Sacramento Valley (DiTomaso and Gerlach 2000). Yellow starthistle's primary means of spread is through human activity. The weed's seed can be transported over long distances by automobiles and earthmoving equipment, and in contaminated soil, crop seed and hay. More locally, the seed can be carried on animal fur and hiking boots and clothing, and by moving water. Wind does not appear to be an effective dispersal method.

\section{Previous infestation estimates}

Since the late 1950s, three estimates of the number of acres infested by yellow starthistle in California have been undertaken (Maddox and Mayfield 1985). The first, by the California Department of Food and Agriculture
(CDFA), used responses from a questionnaire sent to county agricultural commissioners in 1958; the infested acreage of yellow starthistle was estimated at approximately 1.2 million acres (486,000 hectares). A similar survey undertaken by CDFA in 1965 found an estimated 1.9 million infested acres (769,000 hectares).

Donald Maddox and Aubrey Mayfield performed the third estimate 20 years later, in 1985 . They also distributed questionnaires to the county agricultural commissioners but included UC Cooperative Extension farm advisors and other interested parties as well. Maddox and Mayfield estimated the number of acres infested with yellow starthistle at approximately 7.9 million acres (3.2 million hectares), a four-fold increase from 1965.

Unlike the previous two surveys, Maddox and Mayfield (1985) also reported the infested acreage by county and identified those with high and low infestation levels. High infestation counties had at least 1,000 acres (405 hectares) of yellow starthistle. In 1985, 38 of California's 58 coun- 


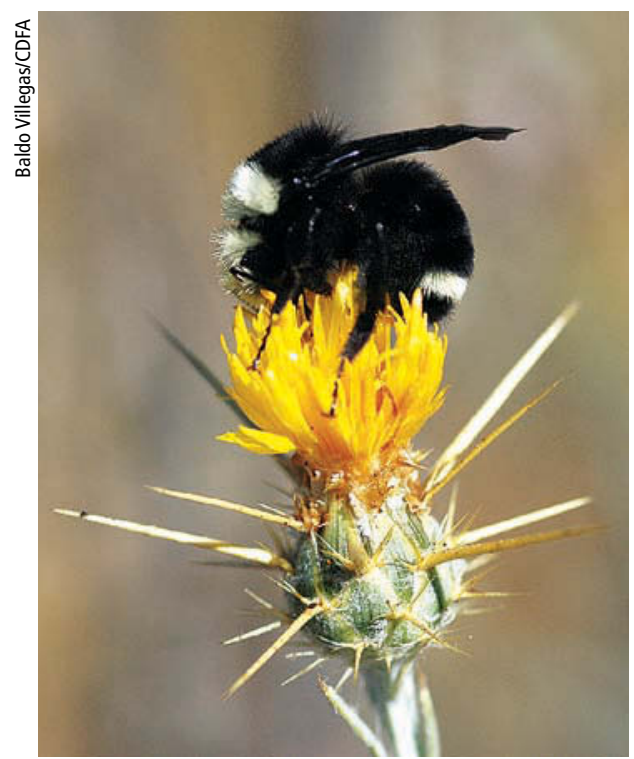

A native plant of southern Europe and northern Africa, yellow starthistle was first recorded in California near Oakland in 1869.

\section{Starthistle abundance guidelines}

The following descriptions were provided to cooperators in the township survey to provide guidance in scoring yellow starthistle abundance.

Low:

- Only a single plant was found in the township.

- The only plants found were scattered plants and confined to the roadsides.

- Plants were scattered throughout the township, but did not occur in high densities.

- No dense patches or a few small, dense patches ( $<10$ acres) were observed.

High:

- Plants occurred primarily along roadsides, and quite dense for several miles.

- Plants not confined to roadsides, but observed throughout neighboring fields.

- Dense patches of plants $>10$ acres found in at least three sections.

- Everywhere you looked you saw yellow starthistle plants. ties had high infestation levels, with Lake County the highest, followed by Siskiyou, Humboldt and Trinity counties. Six counties reported no infestations: Alpine, Imperial, Inyo, Mono, Orange and San Francisco. In addition, Maddox and Mayfield grouped the county estimates into seven regions that represented the state's major drainage areas. The Sacramento and North Coast drainages had the highest infestation acreage, representing over $76 \%$ of the total reported acreage of yellow starthistle for the state.

Maddox and Mayfield's survey showed that the invasion and spread of yellow starthistle in California differed regionally. Northern California had more areas with high infestation levels and Southern California had fewer invaded areas, especially in the South Coast and San Joaquin drainages. This difference was attributed to the Northern California infestations having been in place longer than those in Southern California. Other regions with low infestation levels, such as the higher elevations of the Sierra Nevada and the Sonora and Mojave deserts, were believed to have climates that limit population growth and resist invasion by yellow starthistle.
Knowing the distribution of an invasive weed is of direct importance to its management. If an uninfested area is climatically unsuitable for yellow starthistle, then control efforts may not be necessary. However, if an area susceptible to yellow starthistle has not yet been infested, it might be feasible to control this noxious weed before it becomes abundant and impractical to manage. Studies have shown that controlling exotic weeds at the early stages of invasion is the most successful and cost-effective strategy (Randall 1996; Rejmanek and Pitcairn 2002).

Planning and prioritizing control measures at the regional level requires detailed knowledge of the target weed's distribution. For example, the U.S. Department of Agriculture and CDFA are implementing a statewide distribution effort of several biological control insects for yellow starthistle. For this effort to be successful, it is critical to know where yellow starthistle occurs so that all infestations are targeted for releases (Villegas 2001a, 2001b; Woods and Villegas 2005).

\section{Surveying occurrence by township}

To provide a more detailed and more recent assessment of the spread of yellow

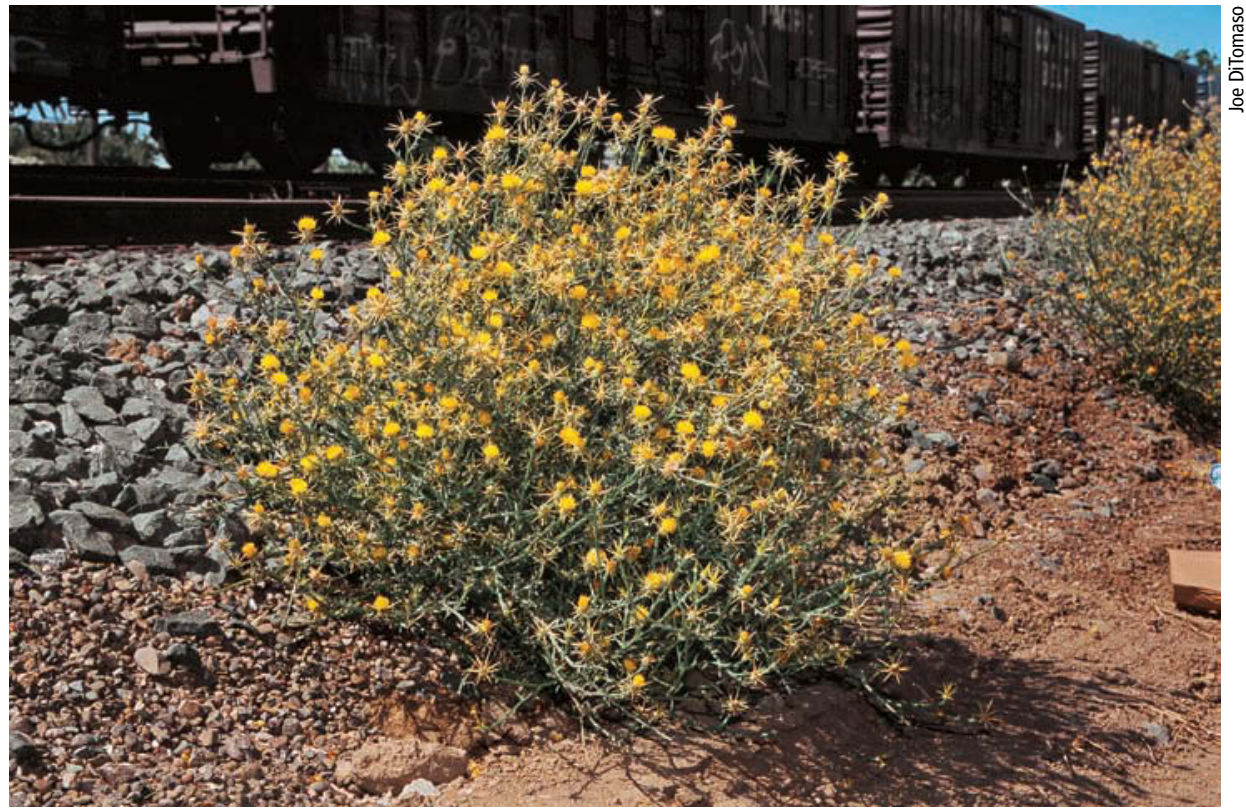

Human activity, such as the use of automobiles and agricultural equipment, is the primary means of dispersal for yellow starthistle seeds. While nontoxic to most animals, it causes neurological diseases in horses. High densities crowd out native vegetation, discourage grazing and annoy hikers. 
starthistle statewide, we performed a survey of its occurrence by township. A legal township in the Federal Public Lands Survey is a 6-mile-by-6-mile square (9.6-kilometers-by-9.6-kilometers). Early land surveyors throughout much of California established townships in the late 1800s. We purchased county maps and used markers to highlight the grid of township borders printed on them. For areas where townships were not established, such as many of the early Spanish land grants, we used markers to extend the grid into those areas.

These marked-up county maps were distributed to CDFA's Weed and Vertebrate Program biologists, who coordinate the eradication of noxious weeds throughout the state. We asked that each township be given a score of " 0 " for no yellow starthistle plants, " 1 " for low abundance and " 2 " for high abundance. Guidelines were provided as to what constituted low and high abundance (see box, page 84 ). Some program biologists completed the maps themselves, while others distributed them to the county agricultural commissioners in their districts. The township grid survey was performed in 1996 and 1997. All information collected during the survey was transferred into a geographic information system (GIS) database and a preliminary map of yellow starthistle in California was produced (Pitcairn et al. 1998).

Sierra Nevada and Kern County. In compiling the township grid data, we learned that knowledge of the occurrence of yellow starthistle was particularly weak or missing in the mid-elevations of the Sierra Nevada and throughout Kern County. Both areas are important transitions from the Central Valley to the mountains in the east and the desert in the southeast, respectively. Before a final map of yellow starthistle in California was produced, we examined these two areas more closely. Information on the occurrence of yellow starthistle in Kern County was provided by the agricultural commissioner's office, which performed a local noxious weed survey in 2000.

In cooperation with the California Department of Transportation, in 1999 we surveyed for yellow starthistle

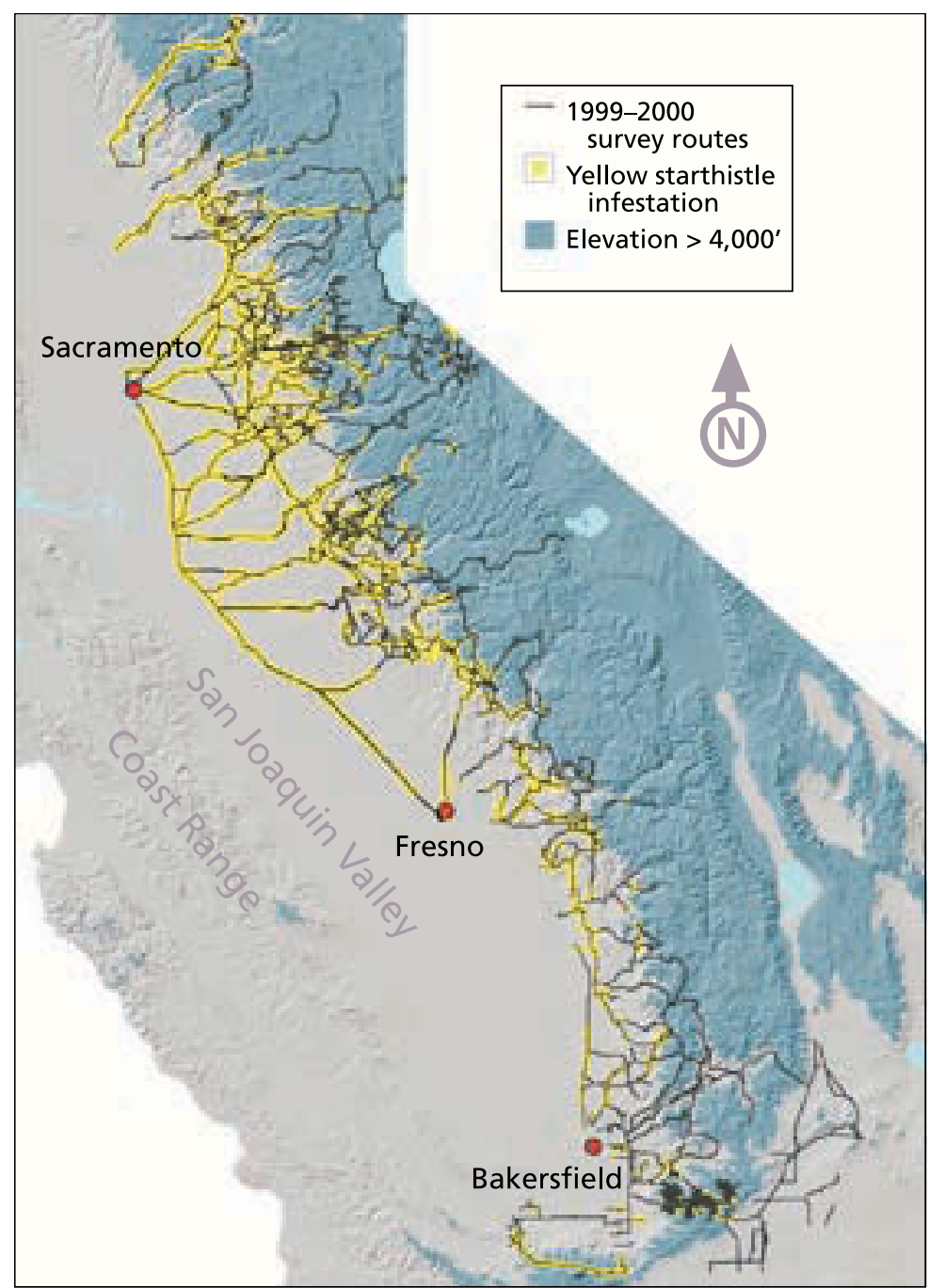

Fig. 1. Surveys of roads in the Sierra Nevada in 1999 and 2000 showed yellow starthistle to be less common at elevations above 4,000 feet $(1,220$ meters).

along 14 major roads crossing the Sierra Nevada as well as along many of the smaller roads in between them. The objective was to identify how far yellow starthistle had spread into the higher elevations. If control efforts were focused on local eradication of new, incipient populations, large tracts of important public and private land might be protected from invasion. In addition, the infested acreage along the advancing front of the invasion might be relatively small and control costs low, especially compared to the value of the area to be protected.

The survey was broken into three phases: a general survey of the highway roadsides, a survey of areas beyond the right-of-way to determine how far yellow starthistle extended away from the roadside, and a resurvey of the upper elevations to determine if plants that germinated later in the season were missed during the survey's first phase. Surveyors used global positioning systems (GPS) to mark yellow starthistle locations, and all data were entered into a GIS database.

In 2000, we coordinated a survey over the same geographic area, taking advantage of the recently formed Weed Management Areas to acquire contacts from many different private and public landowners throughout the region. Weed Management Areas are local coalitions of public and private landowners that work on invasive weeds. They typically include representatives from state and federal agencies with land in the area, land managers from local park districts, large private landowners and concerned citizens. We incorporated 


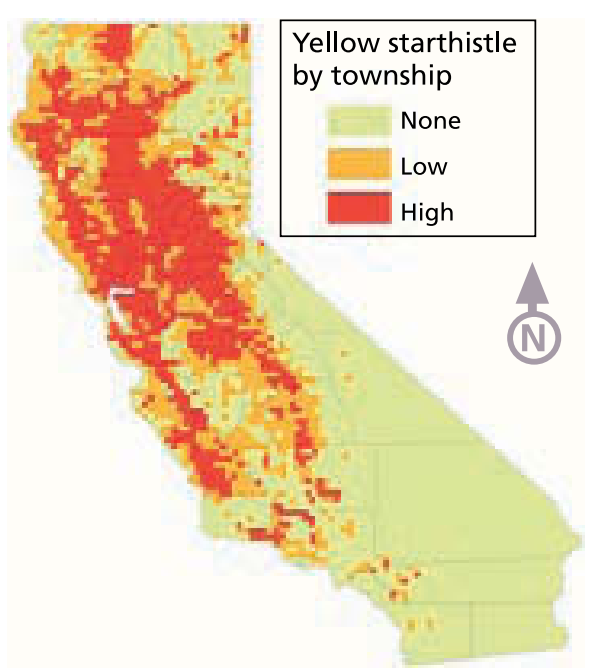

Fig. 2. Occurrence of yellow starthistle by township, incorporating information from all surveys through 2002.

into our database any information on areas surveyed for yellow starthistle or incidental finds collected by cooperators. This included GPS positions, GIS-digitized locations, road descriptions and paper maps. Additionally, we resurveyed some of the highways that were surveyed in 1999 and many of the smaller mountain roads, again using GPS units to record locations.

The results of these two road surveys showed an edge to the spread of yellow starthistle into the Sierra Nevada (fig. 1). When mapped with elevation contours, yellow starthistle was generally not common above elevations of 4,000 feet (1,220 meters). While major highways in the northern Sierra Nevada (such as Interstate 5 and Highway 50) had infestations well above this elevation, yellow starthistle was much less frequent or absent above 4,000 feet (1,220 meters) in the central and southern portion of the mountain range. In addition, while yellow starthistle was common along some roads in the Tehachapi mountains, almost none was observed on the eastern side of mountains in the Mojave Desert.

\section{Modoc County, statewide sur-}

veys. Two more yellow starthistle surveys also became available and were incorporated into our township grid database. First, Modoc County performed a noxious weed survey in 2002, and this information was used to update the township grid data they
TABLE 1. Yellow starthistle infestation totals reported by county agricultural commissioners, 2002

\begin{tabular}{|c|c|c|c|c|c|c|c|}
\hline County & $\begin{array}{l}\text { Total } \\
\text { county acres* }\end{array}$ & $\begin{array}{c}1985 \\
\text { grosst }\end{array}$ & $\begin{array}{l}2002 \\
\text { gross }\end{array}$ & Increase & $\begin{array}{l}\text { Portion county } \\
\text { infested }\end{array}$ & $\begin{array}{c}2002 \\
\text { net }\end{array}$ & $\begin{array}{l}\text { Net/gross } \\
\text { ratio }\end{array}$ \\
\hline & & $\cdots \cdots a c$ & res...... & $\%$ & $\%$ & acres & $\%$ cover \\
\hline Alameda & 528,270 & 20,000 & 200,000 & 900 & 38 & 15,000 & 7.5 \\
\hline Alpine & 465,030 & 0 & 250 & - & $<1$ & 11 & 4.4 \\
\hline Amador & 384,810 & 243,000 & 243,000 & 0 & 63 & 33,000 & 13.6 \\
\hline Butte & $1,065,490$ & 463,000 & 463,000 & 0 & 43 & 50,000 & 10.8 \\
\hline Calaveras & 663,290 & 100,000 & 400,000 & 300 & 60 & 150,000 & 37.5 \\
\hline Colusa & 739,740 & 246,000 & 265,000 & 8 & 36 & 50,000 & 18.9 \\
\hline Contra Costa & 510,680 & 470,400 & 310,000 & -34 & 61 & 44,000 & 14.2 \\
\hline Del Norte & 641,920 & 4 & 1,000 & 24,900 & $<1$ & 1 & 0.1 \\
\hline El Dorado & $1,155,040$ & 5,000 & 650,000 & 12,900 & 56 & 129,000 & 19.8 \\
\hline Fresno & $3,838,820$ & 3,000 & 925,000 & 30,733 & 24 & 303,000 & 32.8 \\
\hline Glenn & 844,160 & 10,000 & 400,000 & 3,900 & 47 & 175,000 & 43.8 \\
\hline Humboldt & $2,303,690$ & 686,000 & 250,000 & -64 & 11 & 50,000 & 20.0 \\
\hline Imperial & $2,942,340$ & 0 & 0 & 0 & 0 & 0 & 0.0 \\
\hline Inyo & $6,462,640$ & 0 & 10 & - & $<1$ & 2 & 20.0 \\
\hline Kern & $5,229,000$ & 100 & 4,500 & 4,400 & $<1$ & 2,500 & 55.6 \\
\hline Kings & 918,790 & 10 & 120 & 1,100 & $<1$ & 100 & 83.3 \\
\hline Lake & 848,960 & 800,000 & 500,000 & -38 & 59 & 176,000 & 35.2 \\
\hline Lassen & $3,001,780$ & 500 & 1,000 & 100 & $<1$ & 500 & 50.0 \\
\hline Los Angeles & $2,610,730$ & 2 & 415 & 20,650 & $<1$ & 125 & 30.1 \\
\hline Madera & $1,374,160$ & 300 & 10,000 & 3,233 & $<1$ & 5,000 & 50.0 \\
\hline Marin & 376,300 & 2,000 & 2,200 & 10 & $<1$ & 1,500 & 68.2 \\
\hline Mariposa & 938,690 & 200,000 & 250,000 & 25 & 27 & 200,000 & 80.0 \\
\hline Mendocino & $2,246,840$ & 250,000 & $1,000,000$ & 300 & 45 & 400,000 & 40.0 \\
\hline Merced & $1,284,930$ & 1,000 & 600,000 & 59,900 & 47 & 120,000 & 20.0 \\
\hline Modoc & $2,777,870$ & 120 & 500 & 317 & $<1$ & 210 & 42.0 \\
\hline Mono & $1,985,950$ & 0 & 1 & - & $<1$ & 1 & 100.0 \\
\hline Monterey & $2,127,430$ & 6,000 & $1,650,000$ & 27,400 & 78 & 56,000 & 3.4 \\
\hline Napa & 510,010 & 242,560 & 242,560 & 0 & 48 & 85,120 & 35.1 \\
\hline Nevada & 635,010 & 200,000 & 248,000 & 24 & 39 & 75,000 & 30.2 \\
\hline Orange & 502,440 & 0 & 0 & 0 & 0 & 0 & 0.0 \\
\hline Placer & 964,140 & 274,000 & 360,000 & 31 & 37 & 145,000 & 40.3 \\
\hline Plumas & $1,675,780$ & 800 & 13,000 & 1,525 & $<1$ & 3,300 & 25.4 \\
\hline Riverside & $4,635,540$ & $251+$ & 2,080 & 729 & $<1$ & 920 & 44.2 \\
\hline Sacramento & 649,780 & 320,000 & 320,000 & 0 & 49 & 25,000 & 7.8 \\
\hline San Benito & 894,150 & 72,000 & 80,000 & 11 & 9 & 8,000 & 10.0 \\
\hline San Bernardino & $12,905,960$ & 2,890 & 1,500 & -48 & $<1$ & 58 & 3.9 \\
\hline San Diego & $2,739,560$ & 15 & 26 & 73 & $<1$ & 8 & 30.8 \\
\hline San Francisco & 58,300 & 0 & 1,000 & - & 2 & 12 & 1.2 \\
\hline San Joaquin $¥$ & 919,180 & 72,000 & 333,143 & 363 & 36 & 38,883 & 11.7 \\
\hline San Luis Obispo & $2,128,800$ & 10,000 & 60,000 & 500 & 3 & 15,000 & 25.0 \\
\hline San Mateo§ণ & 339,690 & 27 & 5,000 & 18,419 & 1 & 5,000 & 100.0 \\
\hline Santa Barbara & $1,756,580$ & 3,000 & 5,720 & 91 & $<1$ & 3,000 & 52.4 \\
\hline Santa Clara & 842,160 & 5,000 & 7,307 & 46 & $<1$ & 7,040 & 96.3 \\
\hline Santa Cruz & 281,360 & 75 & 250 & 233 & $<1$ & 100 & 40.0 \\
\hline Shasta & $2,464,140$ & $400,000+$ & 500,000 & 25 & 20 & 333,000 & 66.6 \\
\hline Sierra & 613,500 & 5 & 364 & 7,180 & $<1$ & 73 & 20.1 \\
\hline Siskiyou & $4,043,710$ & 768,000 & $1,010,000$ & 32 & 25 & 252,500 & 25.0 \\
\hline Solano\# & 558,210 & $20,000+$ & 95,794 & 379 & 17 & 24,906 & 26.0 \\
\hline Sonoma & $1,022,460$ & 100,000 & 100,000 & 0 & 10 & 10,000 & 10.0 \\
\hline Stanislaus & 973,580 & 227,000 & 227,000 & 0 & 23 & 45,050 & 19.8 \\
\hline Sutter & 388,480 & 200,000 & 199,324 & 0 & 51 & 65,450 & 32.8 \\
\hline Tehama & $1,904,640$ & 40,000 & 789,267 & 1,873 & 41 & 137,934 & 17.5 \\
\hline Trinity & $2,062,500$ & 612,672 & 200,000 & -67 & 10 & 50,000 & 25.0 \\
\hline Tulare & $3,100,710$ & 10,000 & 20,000 & 100 & $<1$ & 6,000 & 30.0 \\
\hline Tuolumne§ & $1,467,320$ & 212,818 & 40,000 & -81 & 3 & 40,000 & 100.0 \\
\hline Ventura & $1,192,680$ & 5 & 250,000 & $4,999,900$ & 21 & 100,000 & 40.0 \\
\hline Yolo & 661,760 & 198,600 & 660,760 & 233 & 100 & 165,440 & 25.0 \\
\hline Yuba & 409,020 & 407,680 & 407,680 & 0 & 100 & 80,000 & 19.6 \\
\hline Total & $101,563,500$ & $7,905,834$ & $14,305,771$ & 81 & 14 & $3,682,744$ & 25.7 \\
\hline \multicolumn{8}{|c|}{ * Source: Hornbeck et al. 1983.} \\
\hline \multicolumn{8}{|c|}{ † Source: Maddox and Mayfield 1985.} \\
\hline \multicolumn{8}{|c|}{$\begin{array}{l}\text { ₹ No estimate submitted; gross and net values were estimated as the average of values reported } \\
\text { by Sacramento and Stanislaus counties. }\end{array}$} \\
\hline \multicolumn{8}{|c|}{$\S$ Only net acreage provided. } \\
\hline \multicolumn{8}{|c|}{ I Value provided by San Mateo Weed Management Area. } \\
\hline \multicolumn{8}{|c|}{$\begin{array}{l}\text { \# Only gross acreage provided; net acreage was estimated as } 26 \% \text { of gross acreage (based on the average } \\
\text { ratio between total net and gross acreage for the other counties reporting both values). }\end{array}$} \\
\hline
\end{tabular}




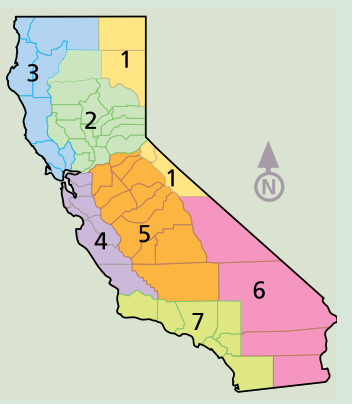

TABLE 2. Comparison of yellow starthistle infestations for major California drainage areas, 1985 and 2002

\begin{tabular}{|c|c|c|c|c|c|c|c|}
\hline \multirow[b]{2}{*}{ Drainage area } & \multicolumn{2}{|c|}{ Gross acreage } & \multicolumn{2}{|c|}{$\%$ of total } & \multicolumn{2}{|c|}{ Net acreage } & \multirow{2}{*}{$\begin{array}{c}\text { Net/gross } \\
\text { ratio }\end{array}$} \\
\hline & $1985^{*}$ & 2002 & 1985 & 2002 & 2002 & $\%$ of total & \\
\hline 1. Northeast interior basins & 58,219 & 1,751 & 0.7 & $<0.1$ & 722 & $<0.1$ & 41.2 \\
\hline 2. Sacramento drainage & $3,235,035$ & $5,872,189$ & 40.9 & 41.0 & $1,635,103$ & 44.4 & 27.8 \\
\hline 3. North Coast drainage & $2,792,186$ & $2,805,760$ & 35.3 & 19.6 & 849,121 & 23.1 & 30.3 \\
\hline 4. Central Coast drainage & 355,042 & $2,313,557$ & 4.5 & 16.2 & 150,152 & 4.1 & 6.5 \\
\hline 5. San Joaquin drainage & $1,458,300$ & $3,052,763$ & 18.4 & 21.3 & 943,533 & 25.6 & 30.9 \\
\hline 6. Southeast desert basins & 2,796 & 10 & $<0.1$ & $<0.1$ & 2 & $<0.1$ & 20.0 \\
\hline 7. South Coast drainage & 4,256 & 259,741 & $<0.1$ & 1.8 & 104,111 & 2.8 & 40.1 \\
\hline Total & $7,907,819$ & $14,305,771$ & 100.0 & 100.0 & $3,682,744$ & 100.0 & \\
\hline
\end{tabular}

had submitted in 1997. Second, CDFA conducted a statewide survey in 2001 and 2002 of biological control agents released against yellow starthistle (Pitcairn et al. 2003). This survey consisted of collecting yellow starthistle plants from 421 locations throughout California and examining them for the presence of four insects known to attack the seed heads. We overlaid the yellow starthistle collection locations on the township map, and then updated the map accordingly.

Final map. The information from all surveys through 2002 was compiled into a final map of yellow starthistle occurrence by township (fig. 2). Of the 6,389 townships statewide, 3,010 had yellow starthistle (1,441 had low abundance and 1,569 had high abundance). These infested townships account for approximately $47 \%$ of the surface area of California. The high-abundance townships occurred primarily in the Sacramento Valley and Sierra Nevada foothills, but were also reported for several coastal valleys from San Luis Obispo County to Humboldt County. The northeast interior and desert basins had few infestations of yellow starthistle.

\section{Number of infested acres}

The township grid map provides our best estimate of the extent to which yellow starthistle has spread, but provides no information on the amount of actual acres infested. To address this question, in 2002 we repeated the questionnaire survey of infested acres performed by Maddox and Mayfield (1985). In contrast to the previous three questionnaires, we requested two estimates of yellow starthistle infestations: gross acreage and net acreage. Gross acreage is the amount of land over which yellow starthistle populations are distributed. This is how the acreage of plant infestations is usually estimated, and how the results from the previous three surveys were reported.

Net acreage is the amount of land actually covered by the yellow starthistle plant canopy. For example, if one 10acre (4-hectare) plot had 100 yellow starthistle plants while another 10 -acre plot had 10,000 plants, the gross acreage in both cases is still 10 acres (4 hectares). However, the net acreage for the plot with 100 plants may be only 1 acre (0.4 hectares), while the net acreage for the plot with 10,000 plants may be 6 acres (2.4 hectares). The ratio of net acres to gross acres multiplied by 100 provides an estimate of the percentage cover of the infestation.

The total gross acreage of yellow starthistle in California is now estimated at 14.3 million acres ( 5.8 million hectares), an increase of over $80 \%$ from 1985 (table 1). Monterey County had the highest reported gross acres of yellow starthistle in the state, at 1.65 million acres (668,000 hectares). This was followed by Siskiyou County with just over 1 million acres (405,000 hectares), Mendocino County with 1 million acres (405,000 hectares) and Fresno County with 925,000 acres (374,000 hectares). In addition, four of the six counties previously reporting no yellow starthistle reported some infestations in 2002; only Orange and Imperial counties still reported none in 2002.

Eight counties reported no change since 1985 in the number of gross acres infested with yellow starthistle, and six counties reported a decrease in infested acres. All other counties reported an increase in infested gross acreage. The largest increase was reported by Monterey County, which jumped from only 6,000 acres (2,430 hectares) in 1985 to 1.65 million acres $(668,000$ hectares) in 2002. The largest proportional increase was reported for Ventura County, which jumped from just 5 acres (2 hectares) in 1985 to 250,000 acres (101,000 hectares).

Per Maddox and Mayfield (1985), we grouped the county infestation acreages by region (table 2). Although our grouping boundaries were not identical to those used by Maddox and Mayfield, they are similar. The differences are due to our grouping of counties as a whole instead of partitioning the estimates according to drainage area. The exception was the reported acreage for Riverside and San Bernardino counties, which occurred entirely within the South Coast drainage area; consequently, estimates from these counties were combined with the South Coast counties.

Our 2002 survey showed that the Sacramento Valley continued to have the largest amount of yellow starthistle gross acreage, with over 5.8 million acres (2.3 million hectares). The San Joaquin Valley followed with just over 3 million acres (1.2 million hectares), then the North Coast drainage with 2.8 million acres (1.1 million hectares) and the Central Coast drainage with 2.3 million acres ( 0.9 million hectares). These four regions represent over $98 \%$ of the total yellow starthistle gross acreage statewide.

Comparing the proportional amounts of the total yellow starthistle infestation located within each region for 1985 and 2002 showed little change except for the Central Coast drainage, which increased from $4.5 \%$ to $16.2 \%$ of the total gross acreage, and the North Coast drainage, which decreased from $35.3 \%$ to $19.6 \%$ of the total gross acreage (table 2). Interestingly, the amount of canopy cover of yellow starthistle (as estimated by the ratio between net and gross acreages) was similar among regions (rang- 


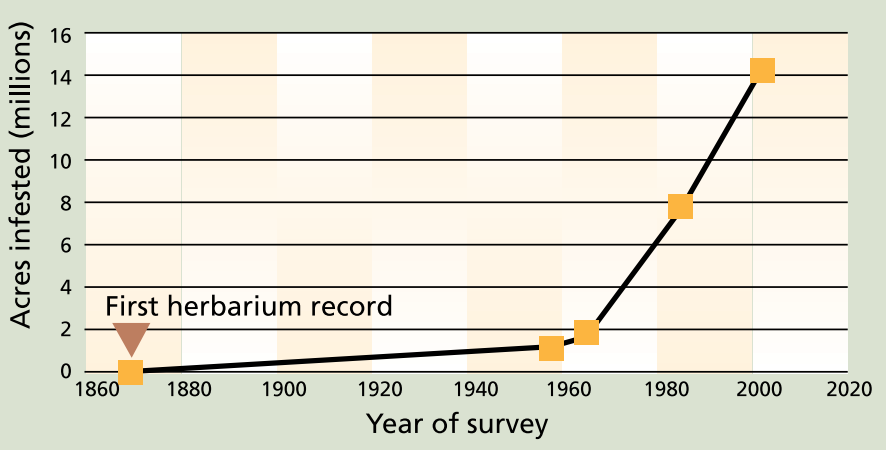

Fig. 3. Number of acres infested by yellow starthistle by year of survey. Sources: Maddox and Mayfield 1985, this report (2002).

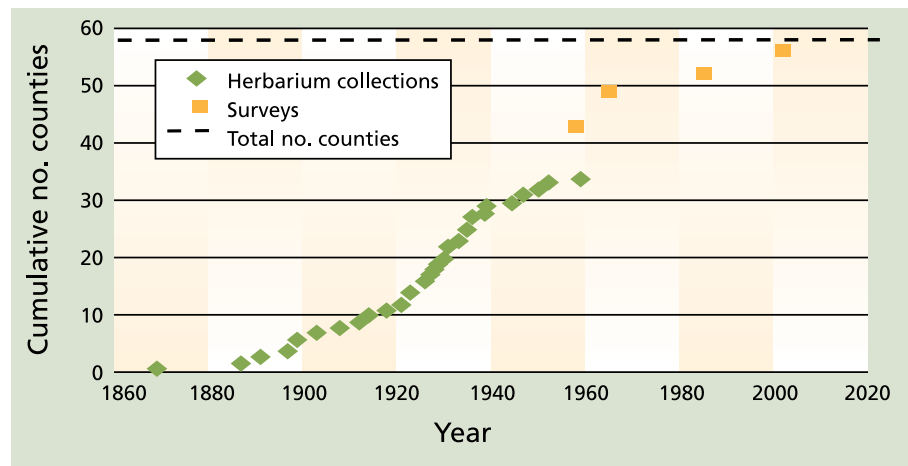

Fig. 4. Cumulative number of counties with yellow starthistle from 1869 through 2002. Data from the herbarium collections compiled by Doug Barbe, CDFA botanist (retired), for 1869 through 1960 (Calflora 2005). Survey data is from questionnaires from 1959 through 1985 (Maddox and Mayfield 1985) and this report (2002). ing from $20 \%$ to $41 \%$ ) except for the Central Coast drainage, which reported an estimated canopy cover of $6.5 \%$. This suggests that, although the gross acreage was high, yellow starthistle cover was actually lower in the Central Coast drainage than elsewhere.

It must be emphasized that our estimates of yellow starthistle acreage are subjective and rely on the judgment of the county biologists. However, an acreby-acre survey would be economically unfeasible. County biologists are trained to identify yellow starthistle and have good firsthand knowledge of the infestations in their county, so a subjective estimate may be our best estimate of infested acreage for an exotic weed that occurs over millions of acres.

\section{Township levels vs. infested acres}

The county survey of infested acres and the abundance of yellow starthistle by township were performed separately. However, we expected that the results of the two surveys were correlated, so to quantify this we summed the amount of acres identified as low or high in the township survey and compared the totals for each county with their estimate of infested acres. There was a significant correlation between the two data sets ( $\mathrm{r}$ $=0.61, P<0.05)$ when we assumed that the high-abundance townships were $45 \%$ infested with yellow starthistle $(10,400$ out of 23,040 acres [4,211 out of 9,328 hectares]) and the low-abundance townships were $17 \%$ infested $(4,000$ out of 23,040 acres [1,619 out of 9,328 hectares]). This suggests that the township abundance survey and the infested acres survey both yielded similar pat- terns of high and low abundance for yellow starthistle.

\section{History of starthistle's spread}

The invasion of California by yellow starthistle shows two phases of spread: a long initial period of slower spread prior to 1960 and a period of rapid spread after 1960 (fig. 3). An initial lag phase has been observed for other exotic weeds and is thought to be due to the weed's genetic adjustment to the new environment and the initiation of enough new founder populations to promote rapid spread (Weber 1998). Some insight into the early invasion dynamics of yellow starthistle may be obtained from the examination of early herbarium records. Doug Barbe, CDFA botanist (retired), visited the main herbaria throughout California and compiled a list of the locations and years of collection for yellow starthistle specimens collected through 1959. A total of 58 localities were obtained and the data were posted on the Internet by Fred Hrusa, the current CDFA botanist (Calflora 2005).

We used these records to examine the patterns of first yellow starthistle occurrence by county and the expansion of the weed's range throughout California (fig. 4). In addition to the herbarium data, we included the numbers of counties reporting infestations in the four surveys between 1959 and 2002. The data shows a logistic curve with the highest rate of increase between 1920 and 1940. There was a decline in new county collections after 1940, when yellow starthistle was no longer considered unusual. Once a species is widely recog- nized as a common weed, the collection of herbarium specimens often declines. However, the addition of the data from the county surveys after 1958 suggests a steady increase in spread from 1920 through 1965.

It appears that during the lag phase of the invasion, yellow starthistle gradually increased in abundance until around 1920, when the rate of spread increased. The earliest herbarium collections occurred within the Sacramento River and North Coast drainage areas (Calflora 2005), but beginning in the 1920s yellow starthistle was collected for the first time in San Bernardino and Santa Barbara counties in Southern California. This was a significant expansion of range.

Gerlach (1997) suggested that invasion of California by yellow starthistle occurred in a multiple-step process. Prior to 1900, yellow starthistle was likely introduced as a contaminant of alfalfa seed brought from Chile. The original source of alfalfa in Chile was Spain, so the yellow starthistle that was initially introduced to California may have been of Spanish origin. After 1900, California received contaminated alfalfa seed directly from several locations throughout Europe and Asia, including Spain, Italy, France, Turkey and "Turkestan" (an area consisting of parts of Turkmenistan, Uzbekistan and Kazakhstan) (Gerlach 1997). This suggests that different biotypes of yellow starthistle may have been introduced during this period.

Individual introductions of a species are only a sample of the genetic diversity of the original source popula- 


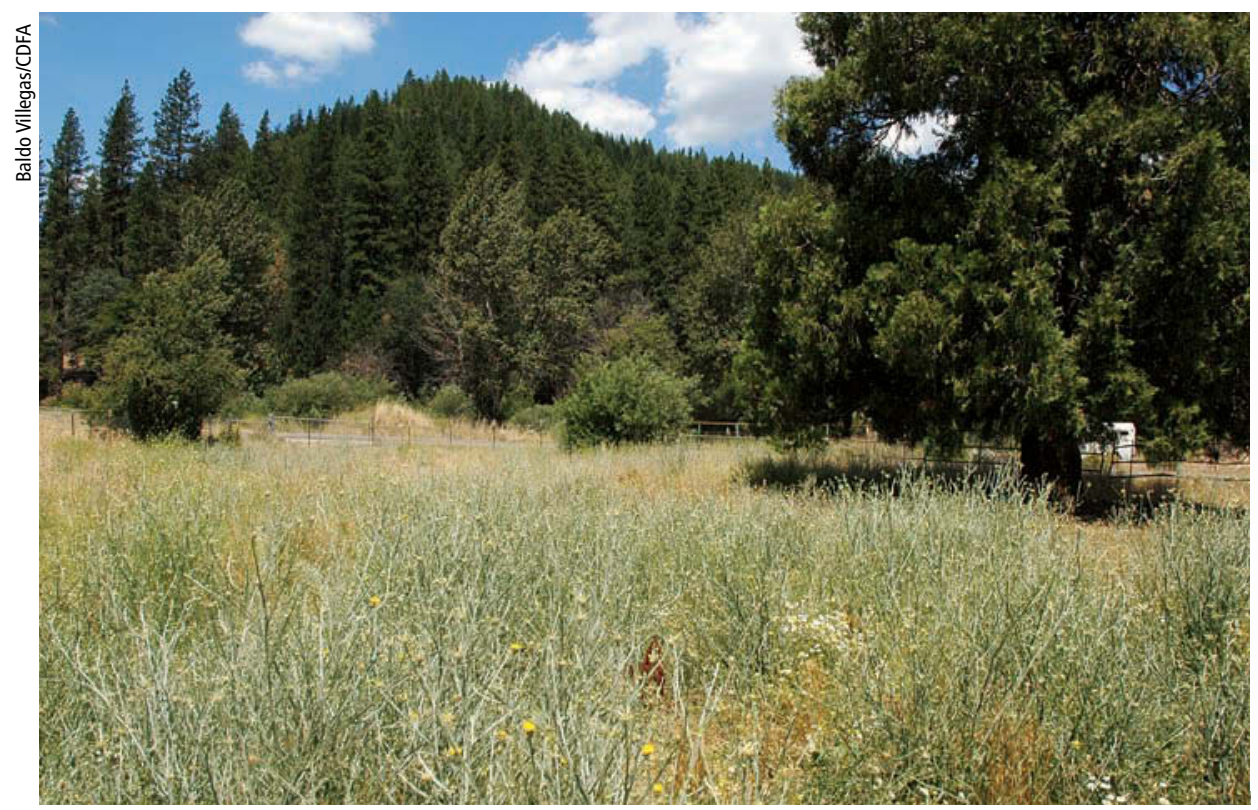

Prior to 1960, yellow starthistle's rate of spread through California was about 13,500 acres annually; between 1965 and 2002 the rate escalated to more than 334,000 acres annually. Above, tall yellow starthistle plants in a pasture near Quincy.

tion, and the lack of genetic diversity may limit a weed's ability to adjust and overcome biotic and abiotic barriers to establishment in its new habitat. The occurrence of multiple introductions and the subsequent hybridization of plants from formerly separated source populations may provide the necessary genetic material to allow a species to become successful in its new environment (Ellstrand and Schierenbeck 2000). The occurrence of multiple introductions of yellow starthistle into California suggests that local hybridization was possible, but its role in the invasion biology of this weed has not been examined.

Gerlach (1997) suggested that a second invasion began in the 1930 s or 1940s, when yellow starthistle became associated with the grazing system being developed for the foothill grasslands. This second invasion was facilitated by changes in cropping practices from 1920 to 1940. Prior to 1920, early reports of yellow starthistle were associated with the irrigated alfalfa fields and dry-land crops (wheat and barley) located near the Sacramento River and its tributaries (Gerlach 1997). Later, with motorized vehicles becoming more common, the cropping systems and harvesting equipment began to move away from the watercourses.

Prior to the 20th century, agricultural production was concentrated near the Sacramento and San Joaquin rivers. Later, with the expansion of the state's irrigation system and the increased use of motorized vehicles, farming expanded away from the river system and into the foothills. The development of new roads into the foothills and the movement of large numbers of grazing animals between the valley and foothills provided an efficient method for yellow starthistle to spread into new areas.

The increase in rate of first occurrence by county (fig. 4) after 1920 is consistent with Gerlach's hypothesis. The movement of yellow starthistle into the foothill grazing system and assistance in its dispersal by the movement of infested agricultural products, animals and machinery, may have been the stimulus that allowed yellow starthistle to move into the second phase of its invasion statewide.

After 1960, the rate of spread of yellow starthistle increased dramatically. The slope of the linear regression of the amount of infested acres between 1965 and 2002 shows that the spread rate was 334,377 acres (135,400 hectares) per year (fig. 3). In contrast, prior to 1960 the rate of spread averaged only 13,500 acres $(5,500$ hectares) per year. A spread rate of 334,377 acres per year is quite high compared to other exotic invasive plants, as most are reported to spread

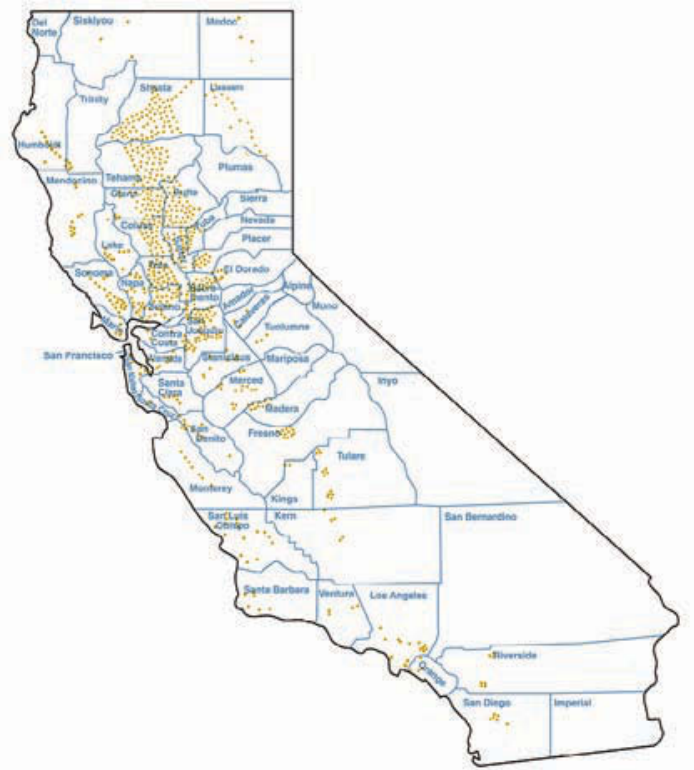

Fig. 5. Historical distribution of yellow starthistle in California, 1941. Source: Robbins et al. 1941.

at rates less than 250,000 acres $(100,000$ hectares) per year (Weber 1998; Smith et al. 1999). Moreover, since 1960 the rate of spread of yellow starthistle in California has been steady, almost linear, and there is no indication of it slowing down. Eventually, however, the rate of spread will decrease as maximum coverage is approached and more aggressive management programs are employed.

The expansion of yellow starthistle throughout California appears to have occurred in two ways: a steady diffusion away from existing population centers, and a disjunctive establishment of multiple satellite populations that were originally separated by great distances but eventually expanded and coalesced. Robbins et al. (1941) produced an early distribution map of yellow starthistle in California (fig. 5) that showed a high concentration of the weed within the Sacramento Valley; several small, scattered populations throughout the remainder of Northern California; and a few small populations in the San Joaquin Valley and the coastal counties of Southern California. This map, along with the early herbarium records, suggests that the initial population center for yellow starthistle was the Sacramento River drainage area. This area continues to have the highest number of infested acres today. 


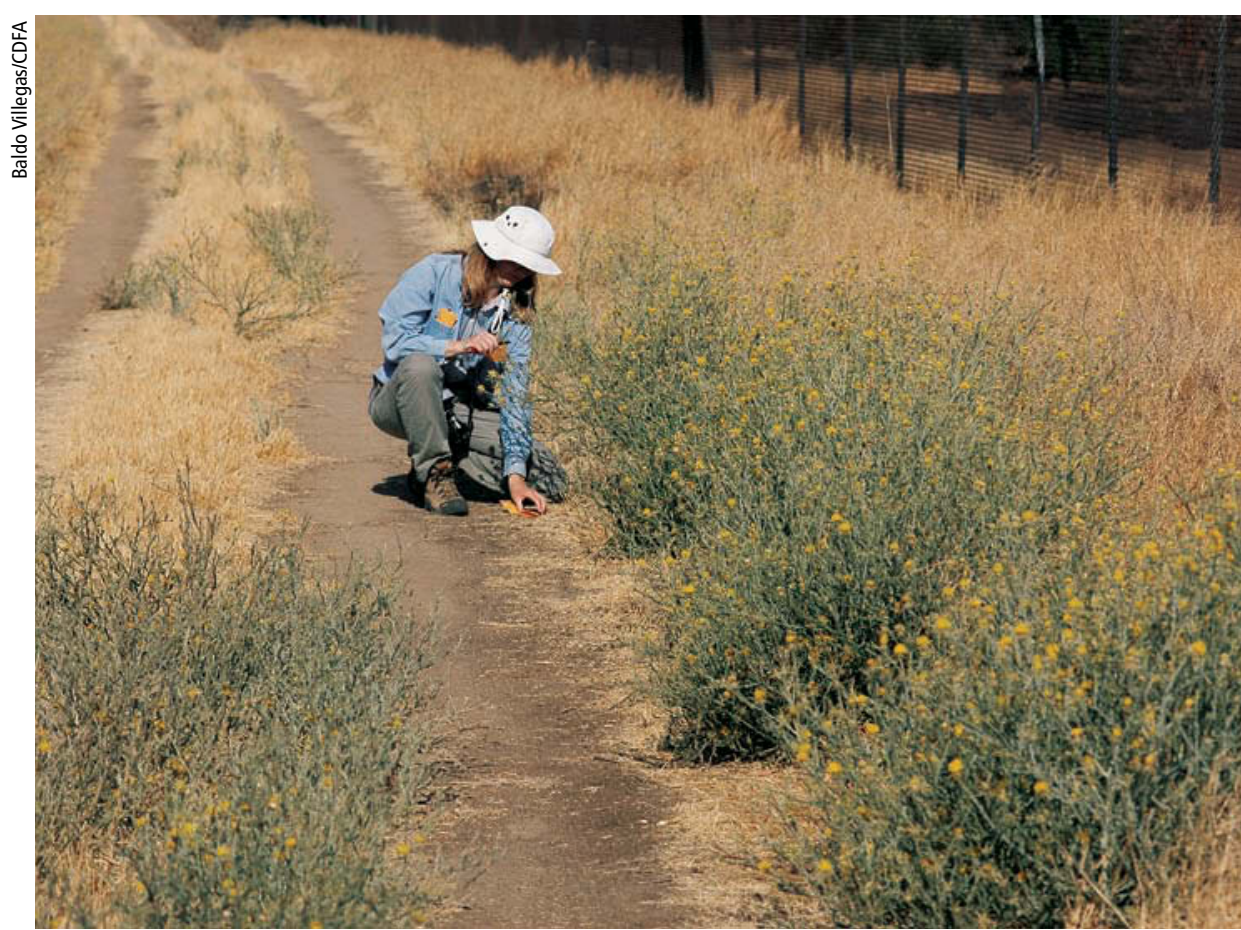

A statewide township survey conducted in 2002 identified more than 14 million gross acres infested with yellow starthistle, nearly double the level of a 1985 survey. Above, U.S. Department of Agriculture scientist Sharon Anderson collects leaf samples along an infested trail in Fresno County.

From 1985 to 2002, increases of infested acres occurred in all areas of the state except the Interior Great Basin and the desert regions. The increases in Southern California likely resulted from new founder populations as well as from the expansion of small existing populations, and these areas showed the highest proportional increases of this weed. However, yellow starthistle infestations in the Sacramento Valley continued to increase, indicating a filling in of the gaps in this area.

\section{Future increases in abundance}

Because this weed has a strong affinity for roadsides and can be transported on machinery and in feed and hay, it is likely that human activity accelerated the scattering of new founder populations and contributed to its high rate of spread. It is not certain how far east and southeast yellow starthistle will spread in the future because environmental factors that may limit its distribution (such as low annual rainfall) are not yet known. However, we anticipate yellow starthistle continuing to increase its density and distribution in both Northern and Southern California, with the highest rates of increase in the southern coastal counties.
Future increases in yellow starthistle abundance may be significant for land managers of areas not currently infested. To stop the spread, new infestations should be eradicated when populations are small and easy to control, taking into account biological control efforts already under way.

\section{M.J. Pitcairn is Senior Environmental Research} Scientist, Biological Control Program, California Department of Food and Agriculture (CDFA), and Associate, Agricultural Experiment Station, Department of Plant Sciences, UC Davis; S. Schoenig is Senior Environmental Research Scientist, Integrated Pest Control Branch, CDFA, Sacramento; and R. Yacoub and J. Gendron are GIS Specialists, CDFA, Sacramento. The authors thank the county agricultural commissioners and their staffs for their cooperation in the surveys summarized here. The authors thank the biologists of the CDFA Weed and Vertebrate Program for their help in the township survey: Al Acosta, Robin Breckenridge, Ron Eng, Ed Finley, Denis Griffin, Rick Keck, Rod Kerr, Butch Kreps, Ross O'Connell, Tom Patrick and David Quimayousie. The authors also thank Reina Kahn and Max JakoVeleski for their assistance with figures 1 and 2 in this article and Marcel Rejmanek and Kevin Rice for comments on an earlier draft of this manuscript. This project was supported, in part, by the California Department of Transportation.

\section{References}

Calflora. 2005. The Calflora Database, Berkeley, CA. www.calflora.org/index0.html (accessed March 25, 2005).

Cordy DR. 1978. Centaurea species and equine nigropallidal encephalomalacia. In: Keeler RF, Van Kampen KR, James LF (eds.). Effects of Poisonous Plants on Livestock. Academic Pr. p 327-36.

DiTomaso JM, Gerlach JD. 2000. Centaruea solstitialis L. In: Bossard CC, Randall JM, Hoshovsky M (eds.) Invasive Plants of California's Wildlands. Berkeley, CA: UC Pr. p 101-6.

Ellstrand NC, Schierenbeck, KA. 2000. Hybridization as a stimulus for the evolution of invasiveness in plants? Proc Nat Acad Sci 97(13):7043-50.

Gerlach JD. 1997. How the west was lost: Reconstructing the invasion dynamics of yellow star-thistle and other plant invaders of western rangelands and natural areas. In: Kelly M, Wagner E, Werner P (eds.). Proc California Exotic Pest Plant Council Symposium, Vol 3. p 67-72.

Hornbeck D, Kane P, Fuller D. 1983. California Patterns: A Geographical and Historical Atlas. Palo Alto, CA Mayfield Publ. $117 \mathrm{p}$.

Maddox DM, Mayfield A. 1985. Yellow starthistle infestations on the increase. Cal Ag 39(6):10-2.

Pitcairn MJ, O'Connell RA, Gendron JM. 1998. Yellow starthistle: Survey of statewide distribution. In: Woods DM (ed.). Biological Control Program Annual Summary, 1997. California Department of Food and Agriculture, Plant Health and Pest Prevention Services, Sacramento, CA. p 64-6.

Pitcairn MJ, Villegas B, Woods DM, et al. 2003 Statewide survey of yellow starthistle biological control agents. In: Woods DM (ed.). Biological Control Program Annual Summary, 2002. California Department of Food and Agriculture, Plant Health and Pest Prevention Services, Sacramento, CA. p 45-9.

Randall JM. 1996. Weed control for the preservation of biological diversity. Weed Technol 10:370-83.

Rejmanek M, Pitcairn MJ. 2002. When is eradication of exotic pest plants a realistic goal? In: Veitch CR, Clout MN (eds.). Turning the Tide: the Eradication of Invasive Species. IUCN SSC Invasive Species Specialist Group. IUCN, Gland, Switzerland and Cambridge, UK. p 249-53.

Robbins WW, Bellue MK, Ball WS. 1941. Weeds of California (1st ed.). California State Department of Agriculture, Sacramento, CA. p 395.

Smith HA, Johnson WS, Shonkwiler JS, Swanson SR. 1999. The implications of variable or constant expansion rates in invasive weed infestations. Weed Sci 47:62-6.

Villegas B. 2001a. Releases of the flower weevil, Larinus curtus, for the biological control of yellow starthistle in California in 2000. In: Woods DM (ed.). Biological Control Program Annual Summary, 2000. California Department of Food and Agriculture, Plant Health and Pest Prevention Services, Sacramento, CA. p 47.

Villegas B. 2001b. Releases of the hairy weevil, Eustenopus villosus, in California during 2000. In: Woods DM (ed.). Biological Control Program Annual Summary, 2000. California Department of Food and Agriculture, Plant Health and Pest Prevention Services, Sacramento, CA. p 48-9.

Weber E. 1998. The dynamics of plant invasions: A case study of three exotic goldenrod species (Solidago L.) in Europe. J Biogeogr 25:147-54.

Woods DM, Villegas B. 2005. Field releases of the rust, Puccinia jaceae var. solstitialis, in California. In: Woods DM (ed.). Biological Control Program Annual Summary, 2004. California Department of Food and Agriculture, Plant Health and Pest Prevention Services, Sacramento, CA. p 25-6. 